\title{
Sinemada Göç Bağlamında Sınıf, Kimlik ve Mekân: Ömer Lütfi Akad ve 'Göç Üçlemesi'
}

\author{
Mücella Ateş \\ Dr. Öğretim Üyesi, Necmettin Erbakan Üniversitesi, m.ates@erbakan.edu.tr (Corresponding Author/Sorumlu Yazar)
}

\begin{tabular}{|c|c|}
\hline e Bilgileri & ÖZ \\
\hline $\begin{array}{l}\text { Anahtar Kelimeler: } \\
\text { Toplumsal sınıf, } \\
\text { Kimlik, } \\
\text { Mekân, } \\
\text { Sinema, } \\
\text { Ömer Lütfi Akad, } \\
\text { Gecekondu, } \\
\text { Göç. }\end{array}$ & 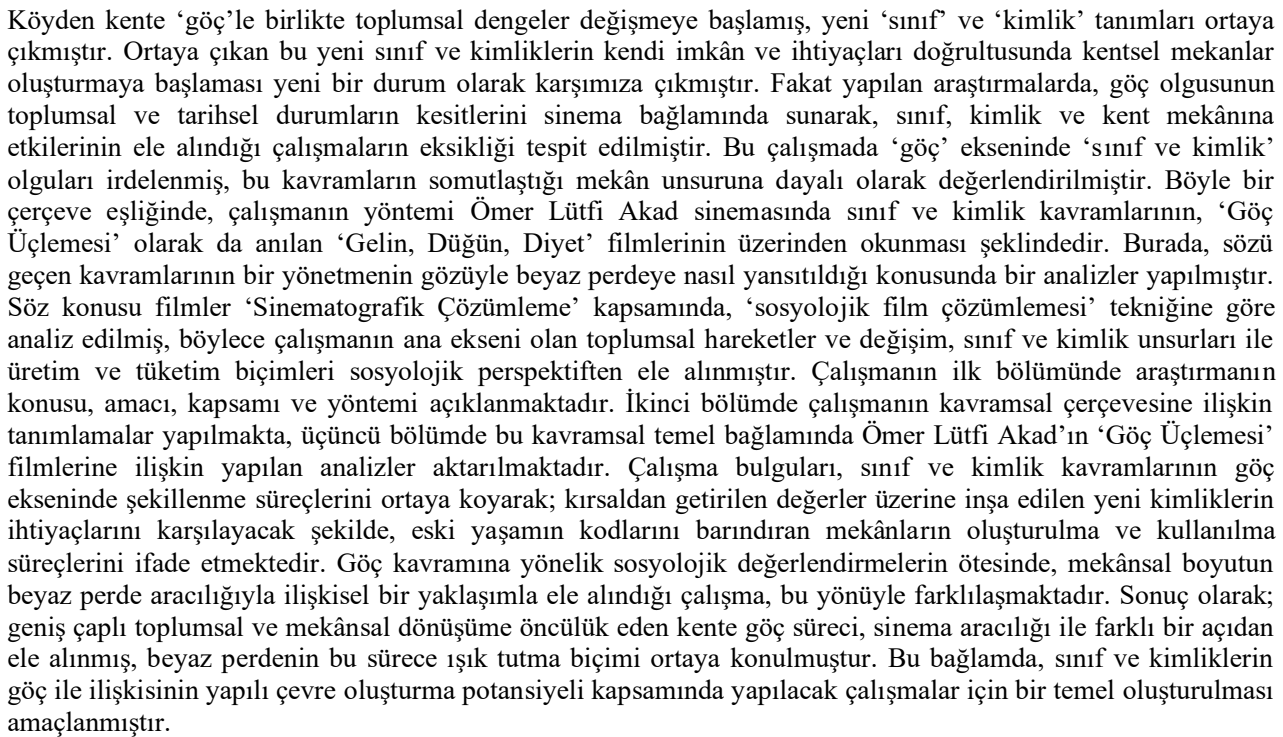 \\
\hline
\end{tabular}

\section{Class, Identity and Space in the Context of Migration in Cinema: Ömer Lütfi Akad and 'Göç Üçlemesi'}

\begin{tabular}{|c|c|}
\hline & ABSTRACT \\
\hline $\begin{array}{l}\text { Article History } \\
\text { Received: } 21.07 .2020 \\
\text { Accepted: } 21.12 .2020 \\
\text { Published: } 31.12 .2020 \\
\text { Keywords: } \\
\text { Social Class, } \\
\text { Identity, } \\
\text { Space, } \\
\text { Cinema, } \\
\text { Ömer Lütfi Akad, } \\
\text { Slum, } \\
\text { Migration. }\end{array}$ & 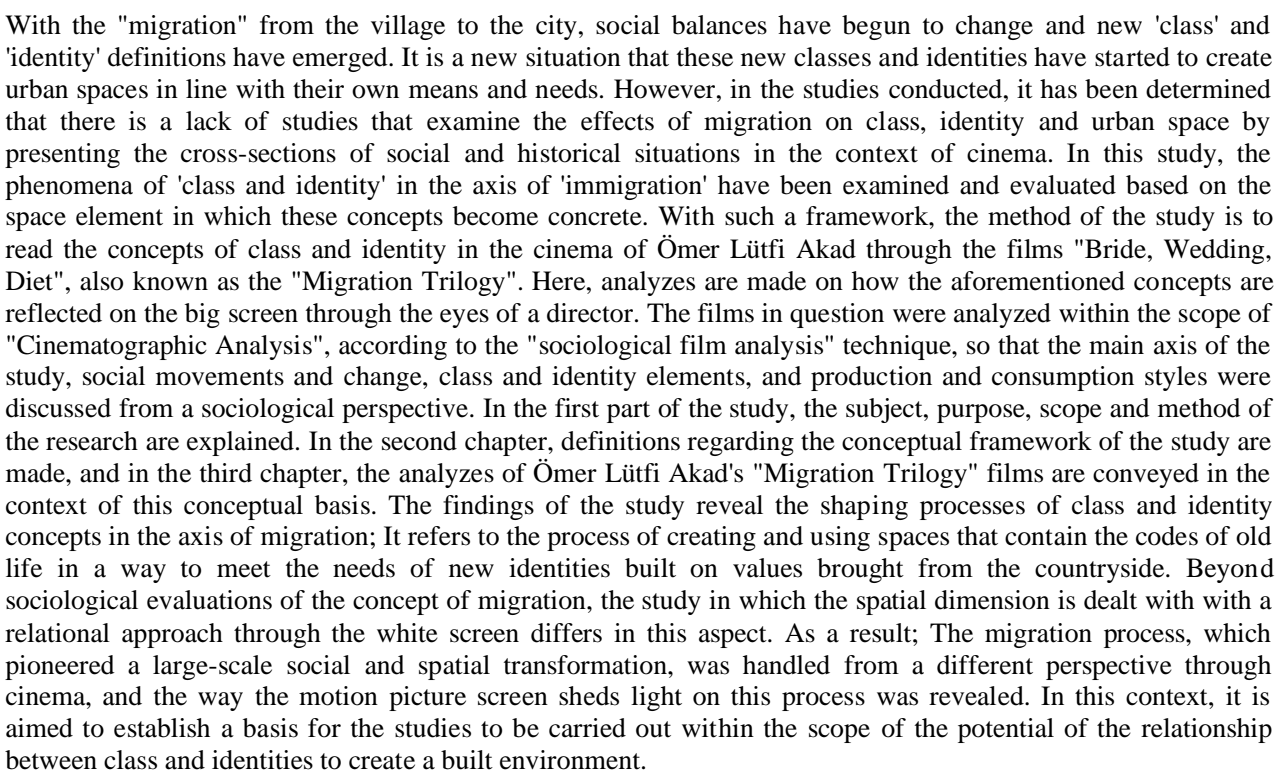 \\
\hline
\end{tabular}

Atıf/Citation: Ateş, M. (2020). Sinemada Göç Bağlamında Sınıf, Kimlik ve Mekân: Ömer Lütfi Akad ve 'Göç Üçlemesi', Medeniyet ve Toplum Dergisi, 4(2), 128-141. 


\section{AMAÇ VE YÖNTEM}

Çalışmanın konusu, köyden kente göç bağlamında oluşan ve dönüşen sınıf ve kimlik biçimleri ile mekan oluşturma ve kullanma süreçlerinin, Ömer Lütfi Akad sineması aracılığıyla okunmasıdır. Bu bağlamda çalışmanın amacı; sınıf, kimlik ve göç olgusunun kuramsal temelleri hakkında özet niteliğinde bir giriş yapılarak teorik bilgi verilmesi ve 70'li yıllarda İstanbul'a göç ekseninde dönemin sınıf, kimlik anlayışının bir yönetmen gözünden sinemaya yansımalarının analiz edilmesidir. Ömer Lütfi Akad sineması ve 'Göç Üçlemesi' bu kavramsal temeller ile ilişki kurularak değerlendirilmiştir. Çalışma böylece, göç olgusuna dair bir boşluğu doldurarak, sınıf-kimlik-mekân ilişkisini sinema çözümleme metodolojisi üzerinden ele almıştır. Film çözümlemesi, filmde yer alan süreçlerin ve öğelerin analiz edilerek, filmin genelinde ortaya koyduğu anlam ve mesajların bütünüdür (Akbulut, 2018: 2-46). Sinematografik çözümleme olarak da ifade edilebilecek olan bu yaklaşım kapsamında Akad'ın Üçleme 'si 'sosyolojik film çözümlemesi' tekniğine göre analiz edilmiş, böylece çalışmanın ana ekseni olan toplumsal hareketler ve değişim, üretim ve tüketim biçimleri sosyolojik perspektiften çözümlenmiştir.Çekildiği dönemdeki sosyal koşulların incelenmesi eksenindeki bu yaklaşımda filmler; toplumdaki değer yargılarını, normları, kimlikleri ve farklı dünya görüşlerini ortaya çıkaracak şekilde analiz edilmektedir (Özden, 2004: 153-165).

Sosyolojik film analizi yöntemi, zaman zaman Marksist, Feminist veya daha başka film çözümleme yöntemleri ile birlikte kullanılsa da, başı başına bir çözümleme pratiğidir. Bu yöntemde, toplumsal olaylar ve roller, değişen kimlikler, yabancılaşma gibi birçok nokta öne çıkmaktadır (Akbulut, 2018: 257258). Bu yöntem ayrıca filmlerdeki ekonomik ve sosyal ilişkilerin tasvir edileceği boyutlar oluşturulmasının önemi üzerinde durmaktadır (Griscbach, 1995: 93). Bu bağlamda, filmlerde yer alan karakterlerin ve toplumsal sınıfların yaşam biçimleri sorgulayıcı bir süzgeçten geçirilir. Böylece, sosyolojik bir film okumasının referans noktalarından birisi olan sınıf kavramı, film dışında kültürel bir bağlama oturtulmaktadır (Özden, 2004: 153-165).

Akad'ın üçleme içinde yer verdiği toplumsal ve sınıfsal süreçlerin göç kavramı ekseninde kurgulanması verilerinin sosyolojik metot ile analizinden elde edilen veriler, buna ek olarak mekân oluşum ve kullanımı ile ilgili kurgulanan sahneler ile ilişkilendirilmiş, böylece kentin fiziksel süreçlerindeki dönüşüm sinemasal mekân zemininde ele alınmıştır. Fizikî veya deneyimlenmiş mekânların beyaz perde aracılığıyla farklı bir gerçeklik düzleminde ortaya konulması demek olan sinemasal mekân olgusu, bu noktada, karakterlerin kullandığı fiziki bir alan olmanın ötesinde, deneyimlenen ve karakterlerin deneyimlerini biçimlendiren, politik, kültürel, toplumsal, ideolojik ve sınıfsal unsurları da kapsamaktadır (Çam, 2016: 7-37). Çalışmada sinemasal mekân çözümlemesi de kullanılmış, göç ve ilişkili olarak ele alınan sınıf, kimlik ve yapılı çevre olgularının, zaman ve mekânla olduğu kadar bir yeri ve anlamı inşa etme sürecini ve filmlerde yer alan karakterlerin toplumsal bağlamı de ortaya konulmuştur.

Yöntemin bir diğer özelliği de filmi, içinde bulunduğu tarihsel döneme ait ürün olarak tariflenen karakterlerin, psikososyal yönlerinin de değerlendirmesinin yapılmasıdır (Özden, 2004: 153-165). Bununla birlikte sosyolojik yaklaşım, belirli sınıfsal özellikler taşıyan karakterler aracılığıyla, sosyal ilişkiler ekseninde, çekildiği döneme ve tarihsel sürece 1şık tutan özelliktedir. Bu bağlamda üçleme içindeki karakterlerin kendilerini, sosyal rollerini, bulundukları toplumun değerlerini anlama ve edinme süreçleri ile dönüşme hikâyelerini de ortaya konularak, yapısalcı ve göstergebilimsel analizlere yer verilmiştir. Bu çözümleme yöntemi, farklı toplumsal katmanların ve dönüşümlerin yer aldığı ve bu eksende karakterlere sahip olan filmlerin incelenmesinde ortaya çıkabilecek yöntem bilimsel sorunların çözümü için de örnek teşkil etmektedir (Özden, 2004: 153-165).

\section{KAVRAMSAL ÇERÇEVE}




\section{Sinıf Kavramı}

Sınıf kavramı, sınıf sosyolojisinin tartı̧̧malı ve tam netlik kazanmayan kavramlarındandır. Ancak toplumbilimlerinde iki ana sınıf yaklaşımı vardır. İlk olarak sınıfın, toplumsal yapının en önemli birimi ve toplumsal tabakalaşma olgusunun bir unsuru olduğu söylenebilir. Toplumsal sınıf konusunda teorileri ile öne çıkan Marx ve Weber bu konuda farklı görüşler ortaya atmaktadırlar. Marx için sınıf toplumun temel taşı, Weber içinse toplumu farklı kılan unsurlardan sadece biridir. Daha sonraki süreçte, endüstrileşme sürecinin ve üretimin fabrikalarda yapılmasının etkisiyle geçim koşullarında da farklılaşmalar olmuş ve sınıf sözcüğü günümüzdeki anlamını o dönemde almıştır (Öngen, 1996:42-46).

Marx ve Weber sınıf olgusunu "ekonomik ilişkiler" temelinde tanımlanmaya çalışırlar. Marx konuyu üretim ilişkilerini çerçevesinde ele alırken, Weber Pazar ilişkilerini temel alır (Arslan, 2004:126143). Sınıf konusunda tam bir tanım yapmanın zorluğu aslında toplumsal yapının ve gerçekliğin de çok karmaşık olmasından ileri gelmektedir. Sınıf ilişkilerinin başlangıç ve bitiş noktaları belli olmadığı gibi, sınıflar da birbirinden kesin çizgilerle ayrılabilen oluşumlar değildir. Bununla birlikte sosyal üretim süreçleri ve teknik-deneysel üretim süreçleri de iç içe geçmiş şekilde toplumun farklı yönlerini oluşturmaktadır. Sınıf yapılanmaları meslek statü, güç ve gelir dağglımı temelinde ayrı ayrı değerlendirilmemeli, bütüncül olarak ele alınmalıdır (Öngen, 1996: 46).

\section{Marksist Sinıf Teorisi}

Kapitalist toplumlarda öne çıkan en önemli kavram olan 'eşitsizlik' konusundaki tartışmalar sınıf olgusunu öne çıkarmıştır. Sınıf teorisinin temeli Karl Marx’a dayanır ve toplumsal gelişmeyi sınıf mücadelelerinin bir ürünü olarak ele alan bu düşünce pratiği, Marksist düşünürler tarafindan formüle edilmiştir. Sınıf teorilerine göre temel düşünce, sınıfların toplumun en temel sosyal güçleri olduğudur.

$\mathrm{Bu}$ noktada üretim biçimi öteki toplumsal, siyasal ve kültürel kurumların belirleyicisidir. Mevcut üretim koşullarında insanlar bir yandan geçinebilmek için üretimde yer alırken, diğer yandan da birbirleri ile etkileşim halindedirler. Toplumdaki ilişkiler üretim sistemine göre şekillenmektedir. Üretim süresince bir yanda üreticiler, diğer yanda ürüne el koyanlar bulunmaktadır. Marx'ın kuramında sınıf ile kastedilen grupların neler olduğundan daha çok, onu oluşturan durumların, başka bir ifadeyle sömürünün kaynağının ne olduğu daha önemlidir. Kapitalist toplumda sınıf mücadelesinin ne gibi temelleri olduğu, sınıf mücadelelerinin nasıl olduğu, önündeki engeller ve sınıf çatışmaları Marksist kuramın temel taşlarıdır. Toplumda sınıfların neden oluştuğunun ve bu sınıflar arasındaki ilişkilerin nasıl olduğunun bilinmesi, sınıf mücadelesini tanımlamak ve bu mücadeleye yön vermek açısından önemlidir (Öngen, 1996: 62-67).

Marx'ın sınıf teorisi endüstriyel kapitalizme dair geniş ve iddialı bir açıklamanın parçasıdır. Marksist bakış açısına göre sınıf olgusu iki açıdan ele alınıp tanımlanmaya çalışılır. Buna göre Marx kapitalizmde sadece iki sınıf olduğunu ifade eder ve bunların üretim araçlarına sahip olan grup ve bu araçlara sahip olmayan dolayısıyla çalışma kapasitelerini, bir başka deyişle emeğini satan grup olduğunu söyler. Bu noktada çalışan ve işveren arasında baş göstermektedir. İşveren bu rekabetçi ortamda kar etmek kaygısıyla çalışanı 'sömürmek' zorundadır. Dolayısıyla burada sosyal değişimi harekete geçiren çatışma durumunun söz konusu olduğu dinamik bir sınıf anlayışının hâkim olduğu söylenebilir (Edgell, 1998: 13-23). Bu durumda söz konusu sosyal sınıflar hem ana aktörler hem de çatışma grupları olmaktadir.

Marx'a göre, Feodal dönem "toprak” temelinde kurgulanmışken, kapitalist dönemde ise bir dönüşüm yaşanmış ve makineleşme ile birlikte, farklı finansal kaynaklar ortaya çıkmıştır. Toprağın yerini artık mekanik donanımlar ve finansal kaynaklar almıştır. Feodal dönemin güç sahipleri, toprağı elinde bulunduran kesim iken, kapitalist dönemde ise, makineleşmeye ayak uydurarak bu alanda gelişen kapitalistlerin yönetici-bir başka deyişle sömürücü- sınıfta olduğunu görmek mümkündür. Bir diğer sınıf 
ise "sömürülen sınıf" tır. Bu sınıftakiler için üretim araçlarının mülkiyetini ve kontrolünü ellerinde bulundurmaları mümkün değildir. Marksist sınıf teorisi; "Sosyolojik Marksist Sınıf Analizi", ve "Yapısalcı Marksist Sinıf Analizi" olarak ikiye ayrılır (Arslan, 2004).

\section{Weberci Sinı Teorisi}

On dokuzuncu yüzy1lın önemli düşünürlerinden olan Max Weber, dinsel düşünce ve bu çerçevedeki değer yargılarının sanayi devrimine etkilerini incelemesiyle bilinmektedir. Protestan ahlakının sanayi devrimine etkileri konusunda devrimin başladığı kentler hakkında incelemeler yapmıştır (Bahar, 2009:5).

Weberci teoriye göre sınıf konumu, pazar konumu ile doğru orantılıdır. Daha açık bir ifadeyle, benzer sınıf konumlarında olan bireylerin yaşam tarzları, hayat algıları, ilgi ve çıkarları da ortak olabilmektedir. "Sınıf konumu" kavramı Marksist ve Weberci teorileri birbirinden ayıran önemli bir noktadır. Weberci sınıf yaklaşımında toplumdaki ticari yaşantı ve bu çerçevedeki ilişkiler belirleyici olurken, Marksist yaklaşımda ise üretim ilişkileri temelinde oluşturulan bir sınıf kavramı vardır (Arslan, 2004:131).

Marx endüstriyel kapitalizme eleştiri getirirken, Weber ise hem modern kapitalizmin rasyonel olma durumunu onaylamış, hem de sosyalizmin karşısında olmuştur. Aynı zamanda bürokrasinin diğer yönetim biçimlerinden daha verimli olduğunu savunur. Weber sosyal tabakalaşmanın farklı biçimlerini analiz etmiş, olumlu ayrıcalıklara sahip sınıflar (mülk sahibi, ticari sınıf), olumsuz ayrıcalıklara sahip sınıflar (özgür olmayanlar, mülksüzler, kalifiye, yarı kalifiye, kalifiye olmayan işçiler) ve orta sınıflar hakkında da çoğulcu görüşler ileri sürmüştür (Edgell, 1998: 21).

Weber'in sınıf yaklaşımında sınıflar birden fazla temele oturur ve hem öznel hem de nesnel olabilirler, dolayısıyla çok katmanlı bir yapı söz konusudur. Weber'in bakış açısına göre sınıfsal bölünmenin mülkiyete dayalı ve toplumsal statü farklılaşmasına dayalı olmak üzere ikiye ayrıldığı söylenebilir. Ona göre kapitalizm çalışanları yoksullaştırmamış, tam tersine daha iyi ekonomik imkânlar sunmuştur, bir endüstri işçisinin bir tarım işçisine göre daha iyi durumda olması da bunu göstergesidir. Weber kapitalizmin sadece emek işçisi ve işveren üzerinden iki kutuplu bir yapı oluşturacağ düşüncesine de karşı çıkar. Sınıf ilişkilerinin farklı girdilerle çok daha fazla çeşitleneceğini savunur aynı zamanda rasyonelleşmenin meydana getirdiği mavi yakalı ve beyaz yakalı ayrımı, iki sınıf arasındaki karşıt durumdan daha önemli olduğu görüşünü dile getirir (Öngen, 1996: 91-92-93).

Daha kısa bir ifadeyle, Weberci anlayışta sosyal sınıfların üç kategoride incelendiği sonucu çıkarılabilir. Bunlardan birincisi mülk sahipleri, ikincisi bilgi ve beceri sahipleri bir diğeri ise iş gücü sahipleridir. Buna ek olarak Weber toplumsal yapının öğelerini sınıfsal yapılanma, statü ve parti olmak üzere yine üç ana grupta değerlendirir (Arslan, 2004:132). Weberci yaklaşımda sınıf, üretim sürecinin bir konumu iken, statü daha çok tüketim anlayışı biçimlerini ifade eder. Bu ikisindeki ortak nokta ise iki kategorinin de güç dağılımının birer ürünü olmasıdır. Statüleri meydana getiren yaşam tarzları ekonomik kaynaklar ile doğru orantılı olduğundan, sınıflar arası hareketlilik temel alınarak statü hiyerarşisi değişebilir denmekte ve bir sosyal hareketlilikten bahsedilmektedir (Öngen, 1996: 97-98).

\section{Kimlik Kavramı}

Farklılıkların vurgulanması şeklinde değerlendirilebilecek bir kavram olan kimlik, kültürle sıkı bir bağ içerisindedir. Bu yönüyle aslında modern toplumda oluşan kimlik bilincinin gelişimini desteklemiştir. Kimlik sosyo-psikolojik bağlamda değerlendirildiğinde ise bireyin "kendisinin ne ve nerede olduğunu açıklaması" şeklinde tanımlanabilir (Akça, 2005:10; Guibernau, 1997: 90-111). 
Bir toplumda kimlik arayışı kavramı ise, modern toplum ürünlerinden olan bireyselleşme sürecini doğurmuştur. Çağımızda kimlik kaygısının önemi yadsınamaz. Bunun nedeninin ise modernlik öncesi dönemlerde, bireylerin doğal ortamında, zaten oraya ait nesnelermiş gibi dururken, günümüzde bireylerin kendi yapay kimliklerini oluşturma durumu olduğu söylenebilir. Bu kırılgan bir süreç olmakla birlikte, birey kimlik olarak kendini nasıl tanımlarsa, yaşam boyu sürecek kimliksel konumlara yerleşmiş demektir (Tutal, 2005).

Daha evvel sözü geçen Marksist teoriye göre, tüm ayrışmalara rağmen varlığını sürdüren işçi sınıfının kimlik öğeleri ve kimlik algısı, cinsiyet ve irktan daha belirleyici bir etkendir. Tam da bundan dolayı, toplumsal kimliğin en önemli unsurunun sınıfsal pozisyonlar olduğu-ifade edilir (Şen, 2012: 89). 'Bu tanımlama bireysel ve toplumsal bağlamda kendimizi algllamamıza olduğu kadar, öteki olarak konumladıklarımızın bizi algıladıkları ve konumladıkları yer ile de ilişkilidir. Bu çerçevede insanların bazılarıyla ortak olan yönlerimize, diğer bazllarından farklllaşan niteliklerimize işaret eden bir aitlik sorunu olması bağlamında kimlik, bireyin kişisel konumunu belirginleştirir ve bireyselliğine sabit özsel bir zemin kazandırır' (Akça, 2005: 10-24; Weeks, 1998: 85).

Sosyal kimlik kavramı, psiko-sosyal anlamda nitelendirilebilecek kimlik kavramıdır ve gruplar arası davranışlar sonucu ortaya çıkan bir kavram olma özelliği gösterir. Sosyal gruplar kendilerini, içinde bulundukları sosyal grupların özellikleri ile tanımlarlar. Dolayısı ile gruplar arası bir karşılaştırma yapmak, sosyal kimliği tanımlamada belirleyici olur. Gruplar arası davranış olgusunu da, toplumların çeşitli gruplar şeklinde bölünmesi sonucunda ortaya çıkan farklı gruplara mensup bireylerin karşılıklı ilişkileri olarak tanımlamak mümkündür (Sözen, 2011: 93-97).

\section{Göç Olgusu}

Göç kavramı, insanların bulundukları ve yaşadıkları yerlerden ekonomik, sosyal, siyasal ve kültürel gibi nedenlerle başka bir yere yerleşmeleri şeklinde tanımlanabilir. Türkiye'de göç olgusunun, 1950'li yıllarda sanayileşmenin etkisiyle ve buna dayalı olarak kentleşmenin ortaya çıkmasıyla hız kazandığını söylemek mümkündür. Tarıma dayalı üretimden sanayi devrimine geçiş, kentlerdeki fabrikaların artması, insanları ve yaşamlarını oldukça etkilemiş, bu durum tarım işçilerinin işsiz kalması ile birlikte, kentlere iş bulmak amacıyla göç etmeye başlamalarını da beraberinde getirmiştir. Ne var ki, köyden kente yönelim birçok sorunu da beraberinde getirmiştir. Kente göç sürecinde, nüfus yoğunluğundan dolayı konut sıkıntısı çekildiği için gecekondulaşma artmış, bununla birlikte çarpık kentleşme baş göstermiştir, gecekondulaşma yoğun olarak görülmeye başlanmıştır. Ayrıca kentlerin hızlı büyümesiyle kentteki sanayi tesisleri kentin içinde kalmış, nüfus artışından dolayı alt yapı hizmetlerinde, sağlıkta ve eğitimde yetersizlikler ortaya çıkmıştır (Terzi, Koçak, 2012:164-167).

"Kırsal kesimden gelen ve cemaat yapısının hâkim olduğu bir kültürden şehre gö̧̧ eden yığınlar "cemaat" yapısını devam ettirmektedirler. Kırsal toplum içerisinde aynı "cemaat" tarzına ait toplumsal alt yapı bulunmadığından "yeni cemaat" yapılarını oluşmaktadırlar. Bu durum "Yeniden kabileleşme" kavramı ile açıklanmaktadır. Anadolu bölgesinden göç edenler için "yeni cemaat" etnik ve kısmen de dini karakterli olabilmektedir. Ayrıca, "gettolaşma" denilen, belirli mahallelere topluca yerleşmeler ve bu bölgelerin nispeten içine kapalı, alt kültür oluşturması durumuna da rastlanmaktadır. " (Sağlam, 2006: $33,42)$

Göçle birlikte, kentin göçüp gelen insanlar üzerinde oluşturduğu etki birçok alanda baş göstermiştir. Özellikle toplumsal ve siyasal örgütlenme düzeyinde, mesleki alışkanlıklarda ve bunun yanı sıra, aile büyüklüğü ve aile içi iletişimde göstermektedir. Aslında, göç ile birlikte yoğunlaşan gecekondu bölgelerindeki göçmenler açısından kentlileşme, tek başına kültürel uyumu değil, iktisadi ve mesleki uyumu da anlatan bir süreçtir. Burada kente göçen insanların meslek değiştirmesi, onların geldiği yerle 
olan ilişkilerini kesmesine ve kente uyum sürecinde ilk adımı atmasına neden olan bir kırılma noktasıdır. Yine bu süreçteki kültürel değişimle birlikte, kent yaşamı özümsenmeye başlanmış, ilerleyen süreçlerde kalabalık aileler yerini çekirdek ailelere bırakmıştır (Özer,2008:8-14).

Alan çalışması olarak incelenen Ömer Lüfti Akad'ın 'Gelin, Düşün ve Diyet' filmleri de göç unsuru ile ilgili çözümlemeler, aile ilişkilerine, kentsel mekânda oluşturulan ve kırsalın kodlarını barındıran yaşam alanlarına, kimlik ve sınıfların oluşumuna yansıyan göç konusunda da ipuçları vermektedir.

\section{Göç Olgusunun Sinemaya Yansımaları}

Sinemayı, olayları sadece yansıtan bir araç olarak değil, sorgulayan, yorumlayan ve yönlendiren bir sanat olarak değerlendirmek gerekir. Aynı zamanda sinema, güçlü bir eğitim aracıdır ve değer yargılarından, ideolojik eğilim ve tutumlardan bağımsız değildir. Bir sinema eseri toplumdaki inançları, değerleri, oluşumları yansıtır ve bu yönüyle toplum için bir tanıktır. Dolayısıyla sinema eserleri, toplumdaki hâkim durumlar ve değişmelerle paralel seyretmektedir. Bunun önemli örneklerinden birini 1970-1980 arası dönem filmlerinde yakından görmek mümkündür. Bu dönem köyden kente göçün yoğun olduğu, bu durumun ortaya çıkardığı bir mekânsal dinamik olan gecekondulaşma ve çarpık kentleşmenin baş gösterdiği bir süreçtir. Sinema filmleri de gerçek hayatla paralel bir şekilde bu konuları oldukça sık işlemiştir. Filmlerde hem göçün sosyal boyutları, hem de mekânsal ve fiziksel boyutları ele alınarak ortaya çıkan çeşitli sorunlar da ifade edilmiştir (Şimşek, 2013: 42-52).

Köyden kente göç edenler beraberinde kan davası, başlık parası karşılığındaki evliliklerin devam etmesi, muhafazakârlık ve kadın ile erkeğin rolü arasındaki denge sorunu gibi unsurları da getirmişler ve bu durumlar da sinemaya başarılı bir şekilde yansıtılmıştır. Bu dönemde göçmenler arasında birincil ilişkilerin yaygın olduğu görülür. Kentteki konut sıkıntısından dolayı inşa edilen gecekondular ve bunun yanı sıra sınırlı istihdam olanakları dolayısıyla göçmenler tarım dışı ekonomik faaliyetleri ifade eden enformel sektöre yönelerek, kendilerine iş bulma durumunda kalmışlardır. Alan incelemesinde yer alacak olan Akad'ın 1970'lerdeki üçlemesi ise kentleşmeyi hem sosyo-ekonomik, hem de sınıf boyutlarıyla irdelemekte ve kentli olmaya dair daha iyimser görüşler savunmaktadır (Şimşek, 2013: 42-45). Yine alan çalışmasına konu olan filmlerden 'Gelin'de bu ataerkil ilişkilerin ve erkeğin bir otorite olarak kabul edilmesinin, onun isteklerine harfiyen uyulmasının, çocuk ve kadınlara söz hakkı verilmemesinin yansımaları görülecektir.

\section{Ömer Lütfi Akad Sinemast}

Türk sinemasının gelişimine bakıldığında, Akad'ın önemli bir rolü olduğu görülür. Türkiye'de toplumsal yaşama paralel olarak ele aldığı konular ve bakış açısı, onu önemli sinemacılar arasına yerleştirmiştir. Halit Refiğ , Akad'ın kişisel üslup sahibi birkaç sinemacıdan biri olduğunu ifade etmiştir. Son dönem sinemasına bakıldığında, Akad'ın sinemasından öğrenilecek birçok husus olduğu görülebilir. Akad meselelere soğukkanlı yaklaşmış, 'meseleleri teşrih etmek' niyetinde olduğunu 'bir reçete getirmek' amacı gütmediğini belirmiştir. $\mathrm{Bu}$ tavır özellikle 'Gelin-Düğün-Diyet' filmlerini anlamanın ve yorumlamanın ipuçlarını sunar. Eğer onun bu bakış açısı anlaşılamazsa, Gelin filminin Meryem'inin duygusal çıkışını, Dügün filmindeki düğüm soru olan kasap çırağı Zeki'nin ' sen iyisin, ben iyiyim, hepimiz iyiyiz de, işler niye böyle oluyor' sorusunu ve Diyet filminde 'ekmek yenilen yerle pazarlık yapılmaz' mantığını anlamak mümkün değildir. Akad sineması gerçekçi ve sosyolojik olarak tanımlanabilir. Özellikle Diyet filminin üzerinden uzun bir zaman geçmesine rağmen, ne kadar doğru tespitler yapıldığı anlaşılabilir. Bunun yanı sıra, sinema alanını aşan ulusal kültür açısından da Akad'ın sinemasının önemsenmesi gerekir (Kayal1, 1994:134-135). 
Akad, üçlemesinde farklı bir açı yakalamaya çalışır. Hızlı şehirleşmenin ortaya çıkardığı gecekondu ortamına paralel olarak, üçlemede bütünsel bir yaklaşım vardır. Radikal değişimlerin ve düzenin sürdürülmesinin salt sosyo-ekonomik tahlillerle değil, değerlerin bu yapısal dönüşümlerdeki etkinliği ve özellikle dönüşümleri gerçekleştirme yöntemi olarak kullanılması Akad'ın bir başka özelliğidir.

\section{'Göç Üçlemesi: Gelin-Düğ̈̈n-Diyet'}

\section{$\operatorname{Gelin}(1973)$}

Akad, üçlemesinde temel olarak, göçün ve şehirleşme sürecinin toplumun esnaf, işportacı ve sendikalaşmaya yönelen işçi gibi farklı sınıflarındaki görüntülerini yansıtmaktadır. Bununla birlikte gecekondular bünyesinde ortaya çıkan sorunlarını de beyaz perdeye yansıtarak, ekonomik sorunların yanı sıra kültürel sıkıntılara da değinmek amacı taşımıştır. Filmlerin önemli yanı insan davranışının sınıfsal temellendirmesini yaparak, kitlelerin sömürülüşünde ve aktif mücadele ettiklerinde haklarını almalarında geleneklerin ve değerlerin önemini vurguluyor olmasıdır. (Kayalı, 1994: 21).

Gelin filmi, şehre gelen ailenin dağıldığı, kötü yollara düşüldüğü, sonunda sağ kalanların yenik olarak memleketlerine geri döndüğü eski dönemlerin romantik göçlerine benzemeyen, Yozgat- Sorgunlu sermaye sahibi Hacı İlyas ve ailesinin göç hikâyesini ele almıştır. Bu kapsamda, esnaf sınıfının, 70’li yıllarda işçi sınıfının, toplumda kadının yeri ile ilgili ipuçlarının, gecekondulaşmanın, göç ile birlikte devam eden feodal düzenin görülmesinin mümkün olduğu bir örnektir. Öykü bir dükkân ve bir gecekonduda geçer. Artık kente gelenler büyüklügün ürküntüsüne kapılmadan, kendini küçümsemeden şehir yaşamına ayak uydurmak için var gücüyle çaba göstermektedir. Zamanla geldikleri yöreye benzer özellikle mahaller oluşturmaya başlayarak, fark edilmeyen bir biçimde kentsel-mekânsal değişimler meydana getirmişlerdir (Akad, 2004: 544).

Film, Hacı İlyas'ın ailesinin kalan kısmının (Gelin Meryem - Hülya Koçyiğit, kocası Veli- Kerem Yılmazer ve oğlu- Kahraman Kıral) İstanbul'a göçüyle başlar. Göç denince akla belki de ilk gelen mekânsal imaj olan Haydarpaşa Garına yanaşan tren, umutları da beraberinde getirmiştir. Eve gidiş yolu vapurladır ve Anadolu'dan gelen bir aile için, büyük yapılar, deniz ve kalabalık oldukça ilgi çekicidir. Hep birlikte yaşayacakları gecekonduya gelirler. Burası tahta bir çitle çevrili, tek katlı, bahçeli bir evdir. Bahçe aynı zamanda evin bir parçası, günlük işlerin bir kısmının yapıldığı, çamaşır asılan, çocukların oynadığı yarı açık bir alan işlevi de görür. Avlu içindeki evde Yozgat düzeni devam etmektedir. Her aileye bir oda olacak şekilde tüm aile birlikte yaşamakta, kadınlar ev işleri ile meşgul olmaktadırlar. Bu yeni mekânsal düzen, kırsaldan göç edenlerin, geldikleri yerde hâkim olan cemaat ve birlikte yaşama kültürüne ait kodların devam ettiğini ifade etmektedir. Aile bir bakkal dükkânı açmış ve şehirde kök salmaya niyet etmiştir. Gecekondu avlusu aynı zamanda bakkal dükkânı için aile içi üretimle yürütülen ticari faaliyetlerin de vukuu bulduğu yer olarak kullanılmaktadır. Tüm amaç, marketi açmak için alınan borçların ödenmesidir. Böylece kentin merkezine gitmek, bakkallı̆̆a alternatif market açarak farklı bir sınıfa dâhil olmak amaçlanır. Ailenin sanayileşme gibi bir düşüncesi olmamakla birlikte, sermayenin büyümesi, holdingleşmesi, söz konusu olmayacaktır. Filmde gecekondunun bahçesindeki çitlerin üzerinden karşı taraftaki apartman blokları görünür, mekânsal anlamda yapılan bu ayrım sınıf ayrımını da somut olarak anlatmakta, çokça tekrarlanan bir replik 'karşı taraflı olmak' aynı zamanda sınıf atlamak anlamına gelmektedir. Büyümek değil, değişmek istenmekte bunun için de aile içindeki sıkıntılar görmezden gelinmektedir, 'çark sürekli dönmelidir' cümlesi dillere pelesenk olmuştur. Tüm bunlar olurken zaten hasta olan ama bu telaşta çok da önemsenmen Meryem'in oğlu daha da kötüleşir. Meryem'in doktora götürme noktasındaki ısrarları yetersiz kalır. Burada ticaretin hacmi arttıkça insanlıktan uzaklaşılmasını görmek mümkündür. 
Özellikle kayınvalide otoritesini koyar ve 'bu avlunun içi Yozgat toprağıdır' diyerek kadının kendi başına karar alamayacağını, aile hiyerarşisi içindeki yerini bilmesi gerektiği noktasında onu uyarır. Bu noktada bir yandan kente uyum sağlamaya çalışan ailenin, gelenek noktasındaki değişiminin nasıl olacağının sinyalleri verilmiş olur. Fakat Hacı İlyas'ın kendi rahatsızlığı ile torununun hastalığı arasındaki çifte standardı da bir çelişki oluşturmaktadır. Bir kurban bayramında, kesilmek üzere bir koç alınır ve evin bahçesindeki ağaca bağlanır. Akad burada çocukla kurbanlık koyun arasında bir paralellik kurar. Dede ve torunun bu noktadaki diyalogları neden böyle bir paralellik kurulduğunun cevabını verir.

Torun (T): Bunu bana mı aldın ă̆ababa?

Dede (D): Yook... Bu kurban olacak.

(T): Kurban nedir?

(D): Gel anlatayım. Vaktin bir evvelinde İbrahim peygamber varmış. Bir de oğlu varmış, adı İsmail. İbrahim peygamber Allah'a inancını göstermek için oğlunu kurban etmek istemiş.

(T): Ŏgluпи ти?

(D): Ŏglunu ya. Götürmüş dă̆ başına.

(T): .Çocuk korkmuş mu?

(D): Korkmamış. Boyun ĕgmiş kadere...

Ve o kurban bayramı öncesi çocuk ölür, Meryem çocuğunu şehre tutunmanın hırsına, daha çok para kazanma ve büyüme düşüne kurban vermiştir. Çocuğun ölmesi bile ailenin bu tavrını değiştirmez, bilakis 'büyük şehrin kavgasında olur böyle şeyler, Allah'1n takdiridir' denir. Gelin'in büyük bir öfke ile gittiği bakkal dükkânındaki sucukları yere firlatıp, Hacı İlyas'a 'etlerini koparsalar bu kadar acımazdı' demesi aslında kentli olabilmek adına çekilen bütün sıkıntılara, umursanmayışlara, feodal düzene bir başkaldırıdır.

Olanları kaldıramayan Meryem evi terk eder. Memleketten daha evvel gelmiş ve kocasıyla birlikte fabrikada işe girmiş bir tanıdık vasıtası ile bir fabrikada iş bularak çalışmaya başlar. Bu tanıdık, karısını çalıştırmasından dolayı aile tarafından sevilmemekte, kadının işçi olması yadırganmaktadır. Fakat onlar bu süreçte feodal yapıdan kurtulmuş, işçi sınıfına entegre olmuşlardır. Bu noktada kadraja işçi sınıfı girer ancak, bu memleketlinin sigortalı olması, mesai saatlerinin belli olması gibi durumlar dışında üçlemenin bu bölümünde bu sınıfa dair fazla bilgi yer almaz.

Gelin'in işe girmesi, geride kalan aile için namus meselesi olur. Veli'nin tabanca verilerek, namusunu temizlemesi söylenir. Bu durum, köyden kente göç olgusunun, kırsal kesimdeki sorunları da beraberinde getirmesi, namus-kan davalarının kentte de devam etmesinin bir örneğidir. Fabrika çıkışında elleri paltosunun cebinde Meryem'i beklemeye başlayan Veli ile Meryem bir süre hiç konuşmadan birbirlerine bakarlar. Daha sonra Veli'nin ağzından dökülen 'bu fabrikada bana da iş bulunur mu?' cümlesi filmin son repliği olur. Kapitalistleşmenin getirdiği yozluğun, göç eden bir ailenin üzerindeki etkisi bir anlamda bilince dönüşmeye başlamıştır.

\section{Düğ̈̈̈n (1973)}

1973 yılında serinin ikinci filmi 'Dügün 'dür. Yola çıkmışken göç ile ilgili ne varsa dökmek gerekmektedir. Şimdi sırada parasız, vasıfsız, birikimsiz göç etmiş insanlar vardır. Bir abla, iki yetişkin erkek kardeş, iki küçük kız kardeş ve bir küçük erkek kardeşten oluşan annesiz ve babasız aile, parasız ve mesleksiz koca şehirde bir başınadır. Aileyi abla bir arada tutar ama hayati kararları büyük erkek kardeş alır. Aile Urfa'dan göç eder. Baba yerine büyük erkek kardeş geçer ve küçük kardeşleri harcamaktan çekinmez. Çocuklar erkek olursa çalışacak, kız olursa başlık parası alınıp satılacak. Abla ise 'insan eti 
yenmeye çalışılan bu düzen'e elinden geldiği kadar direnmeye çalışır. Gelin filminin tersine daha dışa dönük, daha çok mekân unsuru barındıran film, ilk olarak Urfa'dan manzaralarla başlar. İşsizliği, aylaklığ 1 ifade eden görüntülerden sonra İstanbul'da sokaklara kadar taşan kalabalık ve yine iş hayatı ile ilgili görüntüler vardır (Akad, 2004: 550-551).

Urfa'da başlayan film, İstanbul'a göç eden, işsiz, vasıfsız altı kardeşin hayatlarından kesitler sunar. En küçükleri Yusuf, kız kardeşler Habibe-Cemile, erkek kardeşler Halil-İbrahim ve abla Zelha'dır. Zelha satılması için evde lahmacun yapar, dolayısıyla abiler seyyar satıcı, kız kardeşler fabrikada çalışmakta, küçük Yusuf ise okumaktadır. Bir zaman sonra yine büyümenin verdiği hırsla kız kardeşleri evlendirip başlık parası ile birlikte, üç tekerlekli bir araba alarak seyyar satıcılığa o şekilde devam etme kararı alınır. $\mathrm{Bu}$ noktada yine kırsaldan gelen 'başlık parası' gibi gelenekleri görmek mümkün olur. Paraya tapma merkezli olumsuz değişimi simgeleyen, işportacılarla girişilen kavga neticesinde adam bıçaklayan İbrahim yerine suçu küçük Yusuf'un üzerine almasını isteyen abi Halil, kız kardeşlerini de bu uğurda gözünü kırpmadan harcamaktadır. Kardeşlerinin iyiliği için evlenmekten vazgeçip, onlarla İstanbul'a gelen, hem ablalık hem analık yapan Zelha, bu defa kardeşlerinin feda edilmesine göz yummayacaktır. Son olarak başlık parası için satılmış olan Habibe'yi çekip alır ve yeni hayatlarına doğru yola çıkarlar. Gelin filmindeki Meryem gibi, Zelha da kente göç çerçevesinde, tutunmak ve yükselmek için para hırsıyla körleşen aile fertleri karşısında cesur bir tavır sergiler. Akad aynı zamanda Gelin filminde olduğu gibi dini temele dayanan bir argümanı da kullanır. Hazreti Yusuf'u kuyuya atan kardeşlerin kıssası ile küçük kardeş Yusuf'un suçu üstlenmeye zorlanması arasında kurduğu paralellik anlamlıdır. Filmde, seyyar satıcılıktan işi büyüterek küçük ölçekli ticarete kayan bir süreç gözlenmekte ve Habibe'nin başlık parası karşılığında satıldığı, ticaret yapan ve işleri iyi olan Cabbar'ın durumu da değerlendirildiğinde, toplumsal ilişkiler açısından toplumdaki ticari yaşantı ve bu çerçevedeki ilişkilerin belirleyici olabildiği yönündeki Weberci sınıf yaklaşımının izleri görülebilir.

Akad, filmde dramı aile fertleri arasındaki gelişmeler çerçevesinde kurgularken, ekonomik çıkmazlarla göç eden aileyi anlatır. Aile içi çalışmanın da desteğiyle, ihtisaslaşmamış ve örgütlenmemiş seyyar satıcılık ufaktan ticarete kayar. Bu gelişmeler paralelinde aile içi dağılmayı da getirir. Filmdeki karakterlerden salt kötü olan yoktur aslında ancak Habibe'nin sevdiği kasap çırağı Zeki’nin, düğünün yapıldığı yere gelerek dediği gibi ‘ben iyiyim, sen iyisin, hepimiz iyiyiz de işler nasıl böyle oluyor' çıkışı filmin düğüm noktasıdır (Kayalı, 1994: 134-135).

\section{Diyet (1974)}

Üçlemenin son filmi 'Diyet' filmidir. Bu defa söz konusu hikâye düpedüz köylü, kimi zaman yarıcı, kimi zaman ırgat ama her daim tarım işinde çalışmış, yaşlı bir baba (Turgut Savaş), kızı Hacer(Hülya Koçyiğit) ve iki torununun hikâyesi kente göçme, Hacer'in fabrikada çalışmaya başlaması ve işçi sınıfına dâhil olması, böylelikle sendika ile tanışmasının hikâyesini anlatmaktadır. Çalışılan cıvata fabrikasında çok eski olan makineler tehlike saçmakta, ufak bir dikkatsizlikte çalışanların uzuvlarına zarar verebilmektedir. Ustabaşı buraya işçi bulmakta zorlanır. Fabrikada yavaş yavaş sendikalı olmak ve işçi haklarının iyileştirilmesi ile ilgili konuşmalar olsa da, taraftarları fazla değildir. İşçi kesimi kırsaldan göçen ve hala gelinen yerin bakış açısına sahip olduklarından, hakları savunma noktasında fazla bilinçli değiller ve böyle bir davranışın içinde olmayı 'ekmek yenen kapıyla pazarlık yapılmaz' mantığıyla özdeşleştiriliyor. Filmde tüm olay örgüsünün içinde, tüm vasıflarıyla göç etmiş, yabancısı oldukları bir dünyanın içinde kendilerini korumaya çalışan, bildik yaman köy temkinliliği, gelenek ve atalardan gelen bilgelik durumuyla yere sağlam basan sağduyulu tutumlar işlenmektedir (Akad, 2004: 570-571).

Film fabrikada canavar denilen eski makinenin bir işçiyi yaralamasıyla, fabrika ortamında başlamaktadır. Çoğu kimsenin kaderci bir anlayışla yaklaştı̆̆ olaya, sayıları çok da fazla olmayan sendikalı işçiler 'hak' temelinde bakmakta ve tüm işçileri de imkânların iyileşmesini sağlamak amacıyla 
sendikalı olmaya davet etmektedirler ve bunun ancak birlik olmakla mümkün olacağını söylemektedirler. Hacer de diğerleri gibi konuya kayıtsızdır. Kocası habersiz Almanya'ya gitmiş, kendisi çalışıp babasına ve evlatlarına bakmak zorunda kalmıştır. Aslında temelde şehre göçle başlayan işçi olma sürecinde henüz sınıf çıkarlarını gözetip, imkânların iyileşmesini sağlamak için çalışma bilinci ve eylem tarzı oluşmamıştır. Bir süre sonra 'canavar' makinenin başına Hasan (Hakan Balamir) geçer. O da sendikalı olmanın işverene ihanet olacağı düşüncesini paylaşmaktadır. Baba ise şehirde ne iş yapacağını bilemez, köyden sonra kentte yapılabilecek işler bir türlü onu mutlu etmez, bu durumu kabullenemez. 'Ağacı kendi toprağından sökmek' olarak görür kente göç etmiş olmayı. 'Köyde tarlaya tohumu saçınca, gerisi Allah kerim denir. Koca şehirde her an işle güçle uğraşmak, didinmek gerekiyor' der. Balon satmaya karar verdiğinde ise, sokaklarda sesi çıkmaz, elleri titrer. Göçü ve böylelikle içinde düştükleri sıkıntıyı bünyesi kaldıramaz ve ölür.

Öte yandan Hacer ve Hasan'ın yakınlaşmaları evlilikle sonuçlanır. Hacer'in gecekondusunda oturmaya devam ederler. Burası tahta çitlerle çevrili, yoldan birkaç basamakla inilen, birkaç evin aynı avluya baktığı ve bu evdekilerin dayanışma içinde komşuluk ilişkilerini sürdükleri, yemek yenilen, çamaşır asılan, oturulup sohbet edilen bir avludur. Ancak şehirleşmenin bir diğer yüzü olan apartmanlaşma burada baş gösterir ve oturulan gecekondudan çıkmaları istenir, zira ev sahibi evi müteahhitte verip yerine apartman yaptıracaktır. Hacer ve Hasan da kendi evlerini yapmak için kolları sıvarlar. Hafriyat almak için çalıştıkları alanın geri planına bakıldığında, yoğun apartmanlaşma görülmektedir, ancak bu karakterler için hoşa giden ulaşılmak istenen bir durumdur ve yüksek apartmanlara bakılıp 'yükseğe bakmaktan zarar gelmez' der Hasan. Hacer ise 'bir kat olsun, bizim olsun' düşüncesindedir. $\mathrm{Bu}$ sırada fabrika yüklü bir sipariş almış ve bunu yetiştirmek için işçilerden gece de çalışmalarını istemektedir. Tek varlıkları emekleri olan insanlar, iyileştirilmiş hakları gözetmeden kabul ederler. Bu noktada işveren-işçi ilişkisinde de değinilmiştir. İşveren, işçilerin sendikalı olma isteklerine karşı çıkmaktadır. Ona göre herkes onun verdiği ile yetinecek, yetinmezse yerine kolaylıklar kente göç etmiş ve işe ihtiyacı olan biri alınacaktır. Gece mesaisi de kapitalist sistemde işçiden zaman zaman istenen bir durum olarak varlığını sürdürmektedir.

Evlerini tamamlamak için Hacer ve Hasan da gece mesaisini kabul ederler ancak Hacer'in kafasında babasının söylediği Hadis-i Şerif dolaşmaktadır: 'üç ikiden ve iki birden hayırlıdır, birleşiniz'. Akad bu filmde de, üçlemenin diğer iki filminde kullandığı gibi dini bir olguyu kullanarak, bir Hadis üzerinden sosyolojik bir olguyu ifade etmiş ve işçilerin birlik olmasını vurgulamıştır. Bununla birlikte Akad sendikalaşmayı bir Hadisle birlikte gecekondu bölgesine kabullendirmeye yöntemi izlemiştir. Dolayısıyla, halkın değerlerinden faydalanma eğiliminde olmuş ve değerin aslında toplumun değişiminde ne derece rol üstlendiğini göstermeye çalışmıştır. Sonuç olarak Hacer de sendikalı olmuştur ancak buna öfkelenen Hasan, başına gittiği 'canavar' makineye kolunu kaptırır. Kopan kolu alan Hacer bunu patronun yüzüne firlatarak 'al diyetini' diye haykırmıştır. Bu olayda onun tek başına suçlu olmadığını, esas suçlunun işlerini kaybedecekleri endişesi ile birlik olmayan işçiler olduğunu haykırır 'bu suç hepimizin' cümlesi yankılanır.

Genel olarak çalışılan fabrikanın ihtisaslaşma ve örgütlenme düzeyinin geri olduğu görülür. Bunu temel alarak Türkiye'deki genel görünümün doğru saptandığını söylemek yanlış olmaz. Ayrıca sanayi kuruluşu denen yerler orta büyüklüktedir ve bu durum da Türkiye'de kapitalistleşme seviyesinin düşük olduğunu gösterir. İşçi sınıfının gecekondu bölgesinde yaşayan diğer sınıflara nazaran daha iyi bir durumda olduğu, dolayısıyla sorunlarının çözümünün sınıfsal değil, ekonomik olduğu söylenebilir. Filmde ayrıca üretim aracı sahipleri hatasız olarak gösterilmemiş, ekonomik ve hak arayışı mücadelesine karşı oldukları vurgulanmıştır. (Kayalı, 1994: 110- 111). Bu durum, Marx'ın sınıf teorisine göre, üretim araçlarını yönetenlerin, toplumdaki fikirleri de yönetmekte oluğu tespitinin yansıması olarak değerlendirilebilir. 
Filmdeki karakterlerin ortak noktası emeklerini sakınmayan, tek varlığı bilek güçleri olan insanlar olmalarıdır. Üçlemede güçlü duruşu kadınlar üzerinden yakalamaya çalışan Akad, yalın bir gerçeklikle kadınların bu süreçte gösterdiği dirence vurgu yapar. Kadın kimliği üzerinden anlattığı bu güçlü duruş Anadolu kadınının da bir yansımasıdır.

\section{SONUÇ ve DEĞERLENDİRME}

Çalışmada toplumda var olan sınıf ve kimlik ve göç kavramları incelenerek bir kavramsal çerçeve oluşturulmuştur. Kırsaldan kentte göçün dönüştürdüğü sınıf ve kimlik biçimleri ile mekânsal kullanım durumları bu çalışmanın araştırma soruları olarak belirleniştir. Böylece sosyolojik bağlamda çok çeşitli değerlendirmeler yapılan ancak beyaz perdede ve mekânsal kurgu bağlamında yeterli çalışma bulunmayan göç olgusunun, Türk sinemasında nasıl ele alındığı konusu, Ömer Lütfi Akad sineması üzerinden okunmuştur. Bu okuma sosyolojik film çözümlemesi ve sinemasal mekan analizi yöntemleri ekseninde yapılmıştır. Yönetmenin 'Göç Üçlemesi' olarak anılan 'Gelin, Dügün ve Diyet' filmleri bu bağlamda incelenmiş ve 70’li yıllarda salon sineması kuşağının çok ilerisinde, Türkiye gerçekliğini aktarmaya gayret gösteren Akad'ın gözünden bu kavramlar değerlendirilmiştir.

Üç filmde de, büyük kentleri etkileyen, 40’1 y ylların başından beri süregelen büyük göç olayları ile şekillenen sınıflar, kırsaldan getirilen değerler üzerine inşa edilen yeni kimlikler ve bu kimliklerle paralel olan mekânlarda kesitler verilmektedir.

Üçlemenin ilk filmi olan 'Gelin'de Yozgat'tan İstanbul'a göç eden esnaf bir ailenin kök salma ve sınıf atlama çabaları, değer yargıları, ataerkil düzenleri ve yine bu paraleldeki mekânsal düzenleri anlatılırken, kadın kimliğinin tanımı da tartışmaya açılmışır. Bu noktada, kente gelenlerin, büyük şehirden korkmadan şehir yaşamına ayak uydurmak için çabaladığını görmek mümkündür. Mekânsal anlamda he ne kadar çeperlerde, tek katlı ve geleneksel köy yaşamını da kısmen barındıran, kırsal yaşamın etkilerini taşıyan konutlar inşa edilse de, ulaşılmak istenen yer yüksek apartmanların olduğu alandır. Dolayısıyla toplumsal özenti ve sınıf atlama yüksek binalarla simgelenmektedir. Bu noktada, sınıf atlamaya yönelik yapılan planlar, Marksist kuramın temeline atıfta bulunmaktadır. Buna göre sınıf mücadelelerinin nasıl olduğu, önündeki engeller ve sınıf çatışmaları ekseninde bir üretim ve geçim dengesi göz çarpmaktadır. Öte yandan sınıfsal bölünmenin mülkiyete dayalı olarak toplumsal statü farklılaşmasına sebep olduğunu belirten Weber'e göre sınıf atlama olgusunun temelinde mülkiyet yatmaktadir.

Konutlar hem yaşam alanı, hem de günlük işlerin yapıldığı ve sosyal faaliyetlerin yapıldığı bir yarı açık bir alan olmasının yanında, ticari olarak yapılan işlerin de arka planında aile içi üretimle yürütülen ticari faaliyetlerin de gerçekleştirildiği yerdir. Bunun yanı sıra filmde dile getirilen 'avlu içinin memleketi toprağı sayılması' ifadesi, bu mekânsal yapının kırsaldaki gelenekleri de kapsadığı şeklinde değerlendirilmiştir.

İkinci film 'Düğün' de ise vasıfsız bir ailenin Urfa'dan İstanbul'a göçü çerçevesinde, seyyar satıcılık, kırsaldan getirilen adetler (başlık parası), kente uyum sağlamak ve hayatta kalmak için herkesin çaba gösterdiği ve aslında herkesin iyi olmasına rağmen bu düzen içerisinde birilerinin kurban verildiği yine bir gecekondu mahallesinde ve güçlü bir kadın kimliği ekseninde beyaz perdeye yansıtılmıştır. Aile içi çalışmaya dayanan, ihtisaslaşmamış ve örgütlenmemiş ticari faaliyetlerin hazırlıklarının yapıldığı bahçeli tek katlı gecekondu yapılanması burada da önemli bir figürdür. Geleneklerin de beraberinde getirildiği kırsal kimliklerin, güçlü kadın imajı ile sorgulandığı filmde, bu sınıfsal yapıya ait daha fazla mekân unsuru görmek mümkündür. Endüstri işçisinin durumunun, tarım işçisine göre daha iyi olduğunu savunan Weber bakış açısı ile bakıldığında, endüstri çarkına girmemiş ve bireysel çaba ile bahçe mekânında üretim yapılan filmde, ailenin mali ve sosyal durumu ortaya konulmuştur. Büyük çaplı göçler 
ve vasıfsız işçinin artması ile ortaya çıkan işsizlik gerçeği de satır arasında vurgulanan bir diğer önemli mesajdır.

Serinin son filmi 'Diyet' ise yine kente göç eden bir ailenin işçi sınıfına dâhil olma ve işçi sınıfındaki hak arama mücadelesini, göçün kentteki yansıması olan gecekonduları ve buradaki ilişkileri, köylülerin beraberinde getirdikleri kültürleri ile kentli kimliği arasında sıkışmalarını ve bunun kıyaslamasını yine kadın karakteri üzerinden anlatmaktadır. Bu bağlamda serinin bu filmi işçi sınıfına odaklanarak, iş gücünün örgütlenmesi ve sendika üzerinden yeni bir kimlik oluşumuna değinmektedir. Bu bağlamda işverenin de statüsüne değinilen film, bu yönüyle Marx'ın toplumsal gelişmeyi sınıf mücadelelerinin bir ürünü olarak tanımlaması durumunu da vurgulamaktadır. Emek sahibi işçi sınıfı ve üretim araçlarına sahip olan, bir başka ifadeyle emeği satın alan grup üçlemenin bu bölümündeki ilişkileri şekillendiren ana unsurdur. Feodal dönemde toprak sahipleri gücü elinde bulundururken, kapitalist dönemde makineleşmenin güç haline gelmesi durumu, filmde işveren-işçi ve sendikalaşma olguları üzerinden ortaya konulmuştur. Öte yandan, örgütsüz ve ihtisaslaşamadan uzak çalışma biçimi ile birlikte anılan gecekondu mekânları burada da yerini korumakla birlikte, bu alanların yıkılarak yerlerini yüksek binalara ve apartmanlara bırakmaya başladığı bir dönüşüm süresi karşımıza çıkmaktadır.

Üçlemenin filmleri analiz edilirken, sosyolojik analiz ile ortaya konulan toplumsal ilişkiler ve kimliklerin mekânla ilişkili olarak ortaya koyduğu biçimler de sinemasal mekan okuması yoluyla ele alınmıştır. $\quad \mathrm{Bu}$ noktada eylemin gerçekleştiği bir düzlem oluşturan mekânın, sahne olarak işlev gördüğü ortaya çıkmakta ve temsil ve gerçeklik bağlamında, sinemasal anlatıya bir temel oluşturmaktadır. Bu mekânlar ayrıca, karakterin kimliğini ve ait olduğu sınıfı tamamlayan bir unsur olarak filmde yer alarak 'gösteren' şekline gelebilir. Mekânın bu gösterme özelliği zaman zaman, iktidar mücadelelerinin ve sınıfsal çatışmaların mekan düzlemindeki halini de yansıtır (Çam, 2016:22-23). Kente göç sürecinde, gerek düşük gelir durumu gerekse kırsal yaşamda alışılan mekânsal kullanımları devam ettirebilme adına gecekondulaşmanın ortaya çıkarak artış göstermesi, bununla birlikte çarpık kentleşme baş göstermiştir. Bu noktada gecekondu yerleşmeler, göç sürecinin en önemli mekânsal tanığı olarak ortaya çıkmaktadır. Filmlerdeki gecekondu yapısı ve bahçesi, ekonomik, politik, kültürel, toplumsal, ideolojik ilişkilerin bir aracı olarak ifade edilebilir. Kırsalı simgeleyen davranış biçimlerinin rahatça devam ettirildiği, kırsala ait kutsal bir mekan olarak da algılanan bu mekânsal kurgu, sinemayı bu bağlamda jeopolitik bir boyuta taşır.

Tüm bu sonuçlara dayanarak, çalışmanın temelinde yer alan göç kavramının oluşturduğu sınıflar ve kimliklerin mekân bağlamındaki durumu ilişkisel bir yaklaşımla ortaya konulmuştur. Böylece, kırsaldan kente göç olgusunun yarattığı farklı sınıfların ve kimliklerin analizi yapılarak, mekân oluşturma ve kullanma biçimleri değerlendirilmiş, gelecek çalışmalar için bir temel oluşturulması amaçlanmıştır.

\section{KAYNAKÇA}

Akad, Ö. L. (2004). Işılkla Karanlık Arasında. İstanbul: Türkiye İş Bankası Kültür Yayınları.

Akbulut, H., Film Çözümlemeleri [PDF belgesi]. Online Ders Notu : 10 Haziran 2020 tarihinde http://auzefkitap.istanbul.edu.tr/kitap/radyotelevizyonsinema_ue/filmcozumlemeleri.pdf adresinden erişildi.

Akça, G. (2005). Modernden Postmoderne Kültür Ve Kimlik. Muğla Üniversitesi Sosyal Bilimler Enstitüsü Dergisi, (15), 1-24

Arslan, A. (2004). Sınıf Teorisinin Açmazları ve İktidar Analizinde bir Alternatif Olarak Elit Teorisi. Kocaeli Üniversitesi Sosyal Bilimler Enstitüsü Dergisi, (2), 126-143.

Bahar, H.İ. (2009). Sosyoloji. Ankara: Usak Yayınları.

Çam, A. (2016). Sinemasal Mekânlar ve Sinemasal Mekânların Çözümlenmesi. Sinecine, 7(2), 7-37.

Edgell, S. (1993). Sinlf. Ankara: Dost Kitapevi Yayınları.

Griscbach, M. M. (1995). Edebiyat Biliminin Yöntemleri. Ankara: Atatürk Kültür Merkezi Yayım.

Guibernau, M. (1997). Images of Catalonia. Nations and Nationalism, 3 (1), 89-111.

Kayalı, K. (1994). Yönetmeneler Çerçevesinde Türk Sineması. Ankara: Ayyıldız Yayınları. 
Koçak, Y., Terzi, E. (2012). Türkiye’de Göç Olgusu, Göç Edenlerin Kentlere Olan Etkileri Ve Çözüm Önerileri. Kaü-Iibf Dergisi, 3(3), 163-184.

Öngen, T. (1996). Prometheus'un Sönmeyen Ateşi: Günümüzde İşçi Sınıfi. İstanbul: Alan Yayıncılık.

Özden, Z. (2004). Film Eleştirisi, Film Eleştirisinde Temel Yaklaşımlar ve Tür Filmi Eleştirisi. İstanbul: İmge Yayınevi.

Özer, D. (2008). Göç Olgusu ve Kentsel Yaşama Uyumda Yerel Yönetimlerin Rolü, Yerel Siyaset Dergisi, (33), 8-14.

Sağlam, S. (2006). Türkiye'de $\dot{I}_{c ̧}$ Göç Olgusu Ve Kentleşme. Ankara: Hacettepe Üniversitesi Türkiyat Araştırmaları Enstitüsü.

Sözen, E. (2011). Sosyal Kimlik Kavramının Sosyolojik ve Sosyal Psikolojik Bir İncelemesi. Istanbul Journal of Sociological Studies, (23), 93-108.

Şen, F. (2012). Kültürel Kimlikler Karşısında Sınıf Kimliği Ve İşçi Sınıfı Kimliğinin Medyada Temsili (Tekel İşçi Eylemi Örneği). İletişim Kuram ve Araştırma Dergisi, (33), 87-112.

Şimşek, A. (2013). 1980'li Yıllar Türk Sinemasının Kentleşme Olgusuna Yaklaşımı. Sosyal Ve Beşeri Bilimler Dergisi, 5(1), 42-52.

Tutal, N. (2005). Küreselleşme, Illetişim, Kültürlerarasılık. İstanbul: Kırmızı Yayınları.

Weeks, J. (1998). Kimlik: Topluluk, Kültür, Farklılık. İstanbul: Sarmal Yayınevi. 


\section{EXTENDED ABSTRACT}

Social balances started to change with 'migration' from village to city, and new definitions of 'class' and 'identity' emerged. Class and identity created with the concept of migration from rural to urban, creating space and urban use have also emerged as a new situation. However, in the researches, the lack of studies that examine the effects of the immigration phenomenon on the class, identity and urban space in the context of cinema presenting sections of social and historical situations were determined. In this study, the concepts of "class and identity" on the "migration" axis are examined and evaluated based on the element of space where these concepts are embodied. Accompanied by such a framework, it was aimed to make an analysis on how the concepts of class and identity were handled in Ömer Lütfi Akad cinema, and how the concepts mentioned in the "Bride, Wedding, Diet" films, which are also known as "The Migration Trilogy", are reflected on the screen. In the first part of the study, the subject, purpose, scope and method of the research are explained. In the second part, definitions are made regarding the conceptual framework of the study, and in the third part, the analyzes made on Ömer Lütfi Akad's 'Migration Trilogy' films are conveyed in the context of this conceptual basis. In the last part of the study, the results of the research subject are presented. Accompanied by these evaluations; it is seen that the dynamics of creating a cultural-identity, historical process and space in a society can be understood more closely through readings in a wide range of fields, and cinema has important inputs in this context.

The subject of the study is to read how the concepts of class and identity existing in the society are handled in Turkish cinema in the context of migration from village to city through Ömer Lütfi Akad's cinema over the space factor. In this context, the purpose of the study; to give theoretical information about the theoretical foundations of class, identity and immigration, and to analyze the reflections of the class's identity understanding to the cinema in the 70s on the axis of immigration to Istanbul in the 70s. In this context, the study includes the evaluation of the concepts of class and identity in question and the factor of space, which cannot be considered independent from these concepts, in the context of the films "Gelin, Düğ̈̈n, Diyet" directed by Ömer Lütfi Akad. In the first stage of the working method; It is designed to conduct a literature research to obtain theoretical data that will form a conceptual framework, to watch and evaluate the films to be analyzed on this basis, and to obtain the basic resources to source this. Ömer Lütfi Akad cinema and the "Migration Trilogy" have been evaluated by establishing a relationship with these fundamentals. Thus, the study has addressed the class-identity-space relationship through cinema by filling a gap in the phenomenon of immigration.

In the study, a conceptual framework was created by examining the concepts of class and identity and immigration in the society. Class and identity forms and spatial usage situations transformed from rural to urban immigration are determined as research questions of this study. Thus, the subject of how the immigration phenomenon, which was evaluated in a sociological context, but did not have sufficient studies in the context of the screen and spatial fiction, in Turkish cinema was read through Ömer Lütfi Akad cinema. Director of the 'Migration trilogy known as the'Gelin, Dügün, Diyet' films examined in this context and far ahead of the 70s in the halls cinema generations, Turkey was evaluated these concepts through the eyes of Akkadian striving to convey the reality.

In all three films, classes that affect big cities, shaped by major immigration events that have been going on since the early 40s, new identities built on values brought from the countryside and sections in parallel with these identities are given.

The first movie of the trilogy is 'Gelin'. In this film, while describing the rooting and class jumping efforts, value judgments, patriarchal order and spatial order of a family who migrated from Yozgat to Istanbul, the definition of female identity is also opened for discussion.

In the second film, "Wedding", again, in the context of the migration of an unqualified family from Urfa to Istanbul, it is again that everybody tries to adapt to the city and survive, and in fact, although everyone is good, someone is sacrificed in this order. It is reflected on the white screen in the slums and in the axis of a strong women's identity.

The last movie of the series, "Diet", again describes the struggle of a family who migrated to the city to join the working class and to seek rights in the working class. Nevertheless, it recounts the slums, which are the reflection of migration in the city and their relations, the cultures brought together by the villagers, and their comparison between the urban identity and the women's identity. 